\title{
THE WEB OF INTEREST: UNIONS ${ }^{1}$
}

\author{
By J. MORRIS?
}

Oxf. 967

We in the Canadian Labour Congress have always taken a deep interest in the forests because of their importance to the welfare of the nation and we have on numerous occasions urged our governments at both the Federal and Provincial levels to take whatever steps are necessary to make sure that their future is assured. Too many areas of our country formerly covered by heavy forests have become desolate and non-producing because of uncontrolled or clear-cutting practices, and rivers and streams are dry where once there was abundant water. Our forests can only be made to serve the interests of the nation when we develop an effective conservation programme.

However, the major concern of the trade union movement with the forests is and must be with the future of those who harvest its trees and manufacture them into the various products which are so important to our economy. We believe that at long last, due to the great advances in forest technology and management, selective harvesting and production, we have reached the time when stability of markets, production and employment is an attainable goal, and that the problems of seasonal work resulting in a constant turnover of workers can be eliminated and with it the feeling of insecurity that is always with those who work in our forests.

Even though as a trade union group we are primarily concerned with the economic well-being of those who work and live in the forest community, we are also concerned about the forests as our most important renewable resource. The forests are not only the source of raw material for our wood, pulp, paper and chemical industries, they also protect our watersheds as well as providing tremendous recreational facilities for our people. They are also the refuge of much of our wild life. We believe that the national interest demands that the goals of our forest management and administration should be set forth in terms of social objectives that are in the best interests of our people.

Forest management should be used as a tool to build community stability and social well-being. I think there are three aspects of community stability within the framework of the forest policy that have to be considered: forest resources and their rate of renewal, industrial potential and social progress. Briefly, I may describe these points. First, the forest resources should be so managed that a continuing supply of material is available to the industries dependent on them. To ensure this constant supply, compulsory reforestation must be practised by all logging companies and where necessary government regulation should provide for inspection, supervision and enforcement. The forests must be protected from fire and disease and cutting must be planned

${ }^{1}$ Paper presented at the Joint CIF-SAF Meeting, Ottawa, Oct. 1967.

${ }^{2}$ Executive Vice-President, Canadian Labour Congress, 100 Argyle Ave, Ottawa, Ont. 
and selective. Secondly, industrial potential means the maximum manufacturing possible within the limits of investment capital and raw materials available, production costs and market availability to ensure the highest possible employment on a continuing basis. Thirdly, social progress should be determined as serving the best interests of all groups in the community and distributing the rewards of the forest equitably among those dependent on it.

All forest land should be developed for its most productive use and for the permanent good of all and not for the temporary benefit of a few individuals or companies. I believe that the social interests differ from the other two by definition. Good forest management and efficient industrial practices are defined by experts in those fields, but the social goals must be determined and influenced by the articulate groups in the community who care about such things. While I realize that there can be no industrial or community stability without proper forest management, I am also concerned that the needs of industry should not take precedence over the needs or rights of the people and as a trade unionist my prime interest is in people and the factors that count in satisfying their needs, their hopes and their aspirations. 